\title{
A SYNTHESIS AND REVIEW OF MEDICINAL USES, PHYTOCHEMISTRY AND BIOLOGICAL ACTIVITIES OF HELICHRYSUM ODORATISSIMUM (L.) SWEET
}

\author{
ALFRED MAROYI* \\ Department of Botany, Medicinal Plants and Economic Development Research Centre, University of Fort Hare, Private Bag X1314, \\ Alice 5700, South Africa. Email: amaroyi@ufh.ac.za
}

Received: 13 May 2019; Revised and Accepted: 17 June 2019

\begin{abstract}
Helichrysum odoratissimum is an important medicinal plant species in tropical Africa. The current study critically reviewed the medicinal uses, phytochemistry and biological activities of H. odoratissimum. Information on medicinal uses, phytochemistry and biological activities of $H$. odoratissimum were collected from multiple internet sources which included Scopus, Google Scholar, Elsevier, Science Direct, Web of Science, PubMed, SciFinder, and BMC. Additional information was gathered from pre-electronic sources such as journal articles, scientific reports, theses, books, and book chapters obtained from the university library. This study showed that H. odoratissimum is mainly used as an herbal medicine for insomnia, menstrual pain and sterility, and wounds and respiratory problems. Pharmacological research revealed that H. odoratissimum extracts and compounds isolated from the species have antibacterial, antimycobacterial, antifungal, anti-inflammatory, antioxidant, hepatoprotection, and hypoglycemic and cytotoxicity activities. There is a need to validate the documented ethnomedicinal uses of $H$. odoratissimum through phytochemical and pharmacological studies. Therefore, future studies should address these knowledge gaps through experimental animal studies, randomized clinical trials, and target-organ toxicity studies involving $H$. odoratissimum crude extracts and compounds isolated from the species.
\end{abstract}

Keywords: Asteraceae, Helichrysum odoratissimum, Ethnopharmacology, Herbal medicine, Southern Africa.

(C) 2019 The Authors. Published by Innovare Academic Sciences Pvt Ltd. This is an open access article under the CC BY license (http://creativecommons. org/licenses/by/4. 0/) DOI: http://dx.doi.org/10.22159/ajpcr.2019.v12i8.33508

\section{INTRODUCTION}

Helichrysum odoratissimum (L.) Sweet is a perennial shrub which belongs to the tribe Gnaphalieae in the Asteraceae (Compositae) or daisy family. The species has been recorded in Angola, Burundi, Cameroon, Democratic Republic of Congo, Ethiopia, Kenya, Lesotho, Malawi, Mozambique, Nigeria, Rwanda, South Africa, South Sudan, Sudan, Swaziland, Tanzania, Uganda, Zambia, Zimbabwe, and Yemen [1-6]. The genus name "Helichrysum" is derived from the Greek words "Helios" which means "sun" and "Chrysos" which means "gold," in reference to the "golden flowers" which are characteristic of the genus [7]. The specific name "odoratissimum" is in reference to the strong fragrance produced by the species [7]. Synonyms that have been associated with $H$. odoratissimum include Achyrocline hochstetteri A. Rich., A. stenoptera (DC.) Hilliard and B.L. Burtt, Gnaphalium aureofulvum Berg., G. hochstetteri (A. Rich.) Sch. Bip., Graphidium odoratissimum L., Graphidium pedunculare L., Graphidium stenopterus (DC.) Sch. Bip., Graphidium strigosum Thumb., Helichrysum hochstetteri (A. Rich.) Hook.f., H. odoratissimum (L.) Sweet var. lanatum Sond., H. pedunculare (L.) DC., and Helichrysum sarveri S. Moore $[1,2,4,5]$. H. odoratissimum is a heavily branched, bushy, erect, aromatic perennial shrub or occasionally scrambling 20-200 cm high into surrounding vegetation [2,4]. Leaves are variable in shape, usually linear to oblanceolate, narrow at the base or broad and clasping, markedly decurrent, covered in gray to white velvet hairs on both leaf surfaces. The small bright yellow flower heads are crowded in a compound inflorescence at the end of the branches [7]. H. odoratissimum forms large clumps on grassy or rocky slopes in grassland, wooded grassland, thicket, forest edges, disturbed areas and on roadsides at an altitude ranging from $5 \mathrm{~m}$ to $3050 \mathrm{~m}$ above sea level $[2,4,5]$.

The aerial parts, flowers, leaves, roots, stems, twigs and whole plant parts of $H$. odoratissimum are primary sources of herbal medicines in tropical Africa. A patented extract of $H$. odoratissimum is used in the prevention of and treatment of skin cancer in South Africa [8]. Moreover, the leaves, stems, and twigs of $H$. odoratissimum are sold as herbal medicines in the informal herbal medicine markets in Gauteng and the Western Cape provinces in South Africa [9-13]. Research by Van Wyk [14-16] showed that the leaves of $H$. odoratissimum have commercial potential as ritual incense and sedative, while essential oils isolated from the species have commercial potential as an inhalant and aromatherapy in South Africa. Research carried out so far on H. odoratissimum and other plant species showed that these resources are an integral part of traditional pharmacopeia in tropical Africa with a potential contribution to primary health care of local communities in the region [11-18]. Therefore, the current study is aimed at providing a critical appraisal of the existing ethnomedicinal value, phytochemistry and biological activities of $H$. odoratissimum as well as exploring the potential of the species as herbal medicine in tropical Africa.

\section{MEDICINAL USES OF H. ODORATISSIMUM}

The aerial parts, flowers, leaves, roots, stems, twigs, and whole plant parts of $H$. odoratissimum are used for various traditional and medicinal applications in tropical Africa (Table 1). Following medical categorization of human diseases and ailments proposed by Cook [19], Macía et al. [20], Gruca et al. [21], and Staub et al. [22], H. odoratissimum is mainly used for ritual incense, fumigant and perfume and as herbal medicine for insomnia, menstrual pain and sterility, wounds and respiratory problems (Table 1 and Fig. 1). Other medicinal applications recorded in two countries and supported by at least two literature records include the following: Headache, heart problems, insect and parasite repellent, intestinal worms, pain, skin infections, stomach problems, and toothache (Table 1). In Lesotho, the whole plant parts of $H$. odoratissimum are mixed with Olea europaea L. and Zantedeschia albomaculata (Hook.) Baill. as an herbal medicine for backache [23].

\section{PHYTOCHEMISTRY}

$H$. odoratissimum flowers contain the chalcone, helichrysetin, and flavonoids 3,5-dihydroxy-6,7,8-trimethoxy flavone and 3-0-methylquercetinand 3,4',3,5-tetrahydroxy-7methoxyflavone $[24,80]$. The composition of essential oils appears 
Table 1: Medicinal uses of Helichrysum odoratissimum

\begin{tabular}{|c|c|c|c|}
\hline Disease & Parts used & Country & References \\
\hline $\begin{array}{l}\text { Pain (abdominal pains and } \\
\text { backache) }\end{array}$ & Leaves and whole plant & Lesotho and South Africa & {$[8,11,24-27]$} \\
\hline Backache & $\begin{array}{l}\text { Whole plant mixed with Olea } \\
\text { europaea L. and Zantedeschia } \\
\text { albomaculata (Hook.) Baill }\end{array}$ & Lesotho & [23] \\
\hline Colic & Leaves & South Africa & {$[8,25]$} \\
\hline Conjunctivitis & Leaves & South Africa & {$[8,25]$} \\
\hline Cramps & Aerial parts and whole plant & South Africa & {$[11,27,28]$} \\
\hline Diabetes & Whole plant & South Africa & [29-32] \\
\hline Fever & Leaves and stems & South Africa & {$[8,11,25,33]$} \\
\hline Fumigant and perfume & Leaves, stems, and whole plant & $\begin{array}{l}\text { Lesotho, South Africa, and } \\
\text { Swaziland }\end{array}$ & {$[7,11,23,34-44]$} \\
\hline Headache & Leaves, stems, and whole plant & Lesotho and South Africa & {$[11,25,26,31,33,45]$} \\
\hline Heart problems & $\begin{array}{l}\text { Aerial parts, leaves, roots, and whole } \\
\text { plant }\end{array}$ & Lesotho and South Africa & {$[24-28,46-48]$} \\
\hline Induce vomiting & Leaves & South Africa & [25] \\
\hline Inflammation & Whole plant & South Africa & {$[27]$} \\
\hline Insanity & Leaves and twigs & South Africa & {$[11,27]$} \\
\hline Insect and parasite repellent & Leaves and whole plant & Lesotho and South Africa & {$[7,11,27,39,42,43,49]$} \\
\hline Insomnia & Leaves, roots, stems, and whole plant & $\begin{array}{l}\text { Lesotho, South Africa, and } \\
\text { Swaziland }\end{array}$ & $\begin{array}{l}{[7,8,11,25,33,37,39} \\
43,49-53]\end{array}$ \\
\hline Intestinal worms & Roots and whole plant & Kenya and South Africa & {$[54,55]$} \\
\hline Kidney problems & Aerial parts & South Africa & {$[27,28]$} \\
\hline Laxative & Leaves & South Africa & {$[25]$} \\
\hline Magic & Whole plant & South Africa & {$[27]$} \\
\hline Menstrual pain and sterility & Leaves and whole plant & Lesotho, Rwanda, and South Africa & {$[8,24-27]$} \\
\hline Nervous disorders & Leaves & South Africa & {$[46,48]$} \\
\hline Postpartum bleeding & Leaves & South Africa and Tanzania & {$[27,56]$} \\
\hline Prostrate problems & Whole plant & South Africa & {$[27]$} \\
\hline $\begin{array}{l}\text { Respiratory problems (chest } \\
\text { pains, colds, cough, flu, and } \\
\text { tuberculosis) }\end{array}$ & Leaves, roots, stems, and whole plant & $\begin{array}{l}\text { Lesotho, South Africa, Tanzania, } \\
\text { Uganda, and Swaziland }\end{array}$ & $\begin{array}{l}{[7,8,11,23-28,31} \\
33-38,41,43,46-53,55-66]\end{array}$ \\
\hline $\begin{array}{l}\text { Skin infections (acne, eczema, } \\
\text { pimples, scabies, and skin } \\
\text { ulcers) }\end{array}$ & $\begin{array}{l}\text { Flowers, leaves, stems, and whole } \\
\text { plant }\end{array}$ & Rwanda and South Africa & $\begin{array}{l}{[7,8,24,36,38,50-52} \\
58,69-72]\end{array}$ \\
\hline $\begin{array}{l}\text { Stomach problems and } \\
\text { excessive bile }\end{array}$ & $\begin{array}{l}\text { Aerial parts, leaves, stems, and whole } \\
\text { plant }\end{array}$ & Lesotho and South Africa & {$[26,28,33]$} \\
\hline Stroke & Leaves and roots & South Africa & {$[47]$} \\
\hline Tension & Leaves and twigs & South Africa & {$[11]$} \\
\hline Toothache & Leaves and stems & South Africa and Uganda & {$[33,73-76]$} \\
\hline Urinary problems & Whole plant & South Africa & {$[27]$} \\
\hline $\begin{array}{l}\text { Wounds (including burns and } \\
\text { infections) }\end{array}$ & Leaves, roots, twigs, and whole plant & $\begin{array}{l}\text { Cameroon, South Africa, and } \\
\text { Tanzania }\end{array}$ & $\begin{array}{l}{[11,24,25,31,43,49,55-} \\
59,72,77-79]\end{array}$ \\
\hline
\end{tabular}

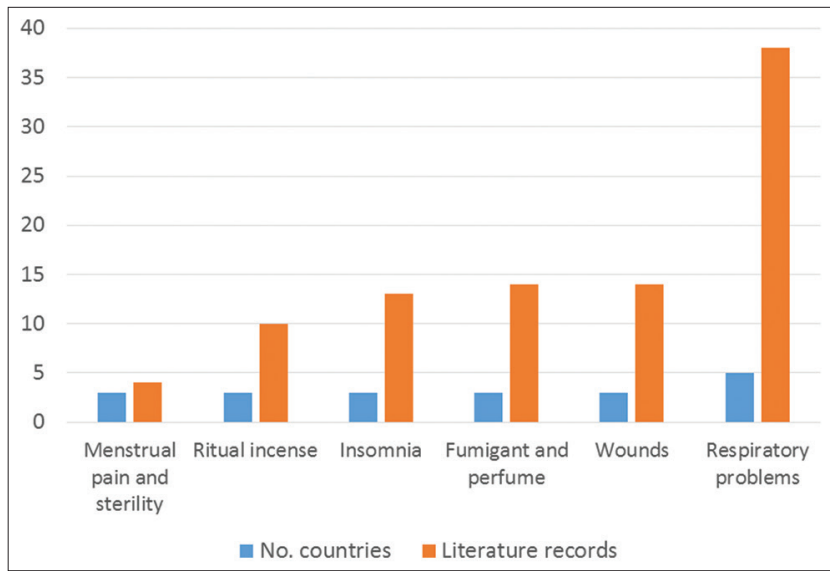

Fig. 1: Traditional and medicinal applications of Helichrysum odoratissimum in tropical Africa to vary with geographical origin of the specimens as shown in Table 2. The major compounds that have been identified from the species include(Z)- $\beta$-ocimene $(<0.01-10.8 \%)$, docosanoic acid methyl ester (11.4\%), bifloratriene (7.4-11.6\%), germacrene A (1.1$11.8 \%), \delta$-cadinene $(0.3-13.2 \%)$, humulene $(14.1 \%), \alpha$-humulene (<0.01-14.6\%), 1,22-docosanediol (15.1\%), (E,E)-farnesol (16.8\%), 1,8-cineole (2.7-17.1\%), 1-isopropyl-3-methylbenxene (18.3\%), $\alpha$-curcumene (4.0-20.3\%), caryophyllene oxide $(0.1-20.6 \%)$, $\beta$-caryophyllene $(1.3-25.2 \%)$, palmitic acid $(27.1 \%)$, limonene $(<0.01-31.6 \%)$, pelugone (34.2\%), p-menthone (35.4\%), $\alpha$-pinene (1.1-47.1\%), and $\beta$-pinene $(0.1-51.6 \%)[38,42,43,51,65,75,78,79,81-$ 84]. Future research should focus on evaluating the biological activities of the isolated compounds.

\section{BIOLOGICAL ACTIVITIES}

The following biological activities have been reported from $H$. odoratissimum crude extracts and compounds isolated from the species: Antibacterial [24,38,42,61,74,75,85-87], 
Table 2: Phytochemical composition of Helichrysum odoratissimum

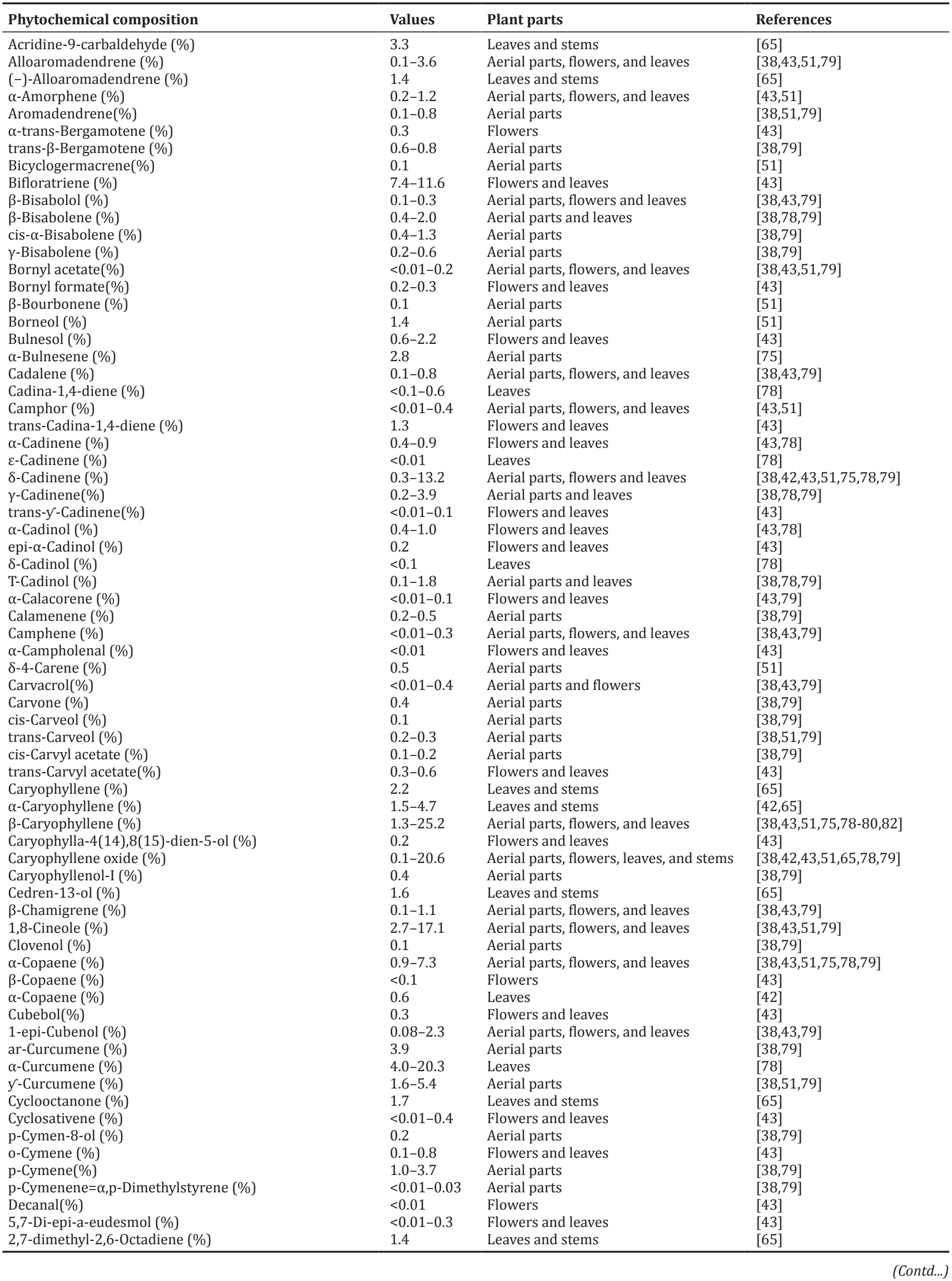


Table 2: (Continued)

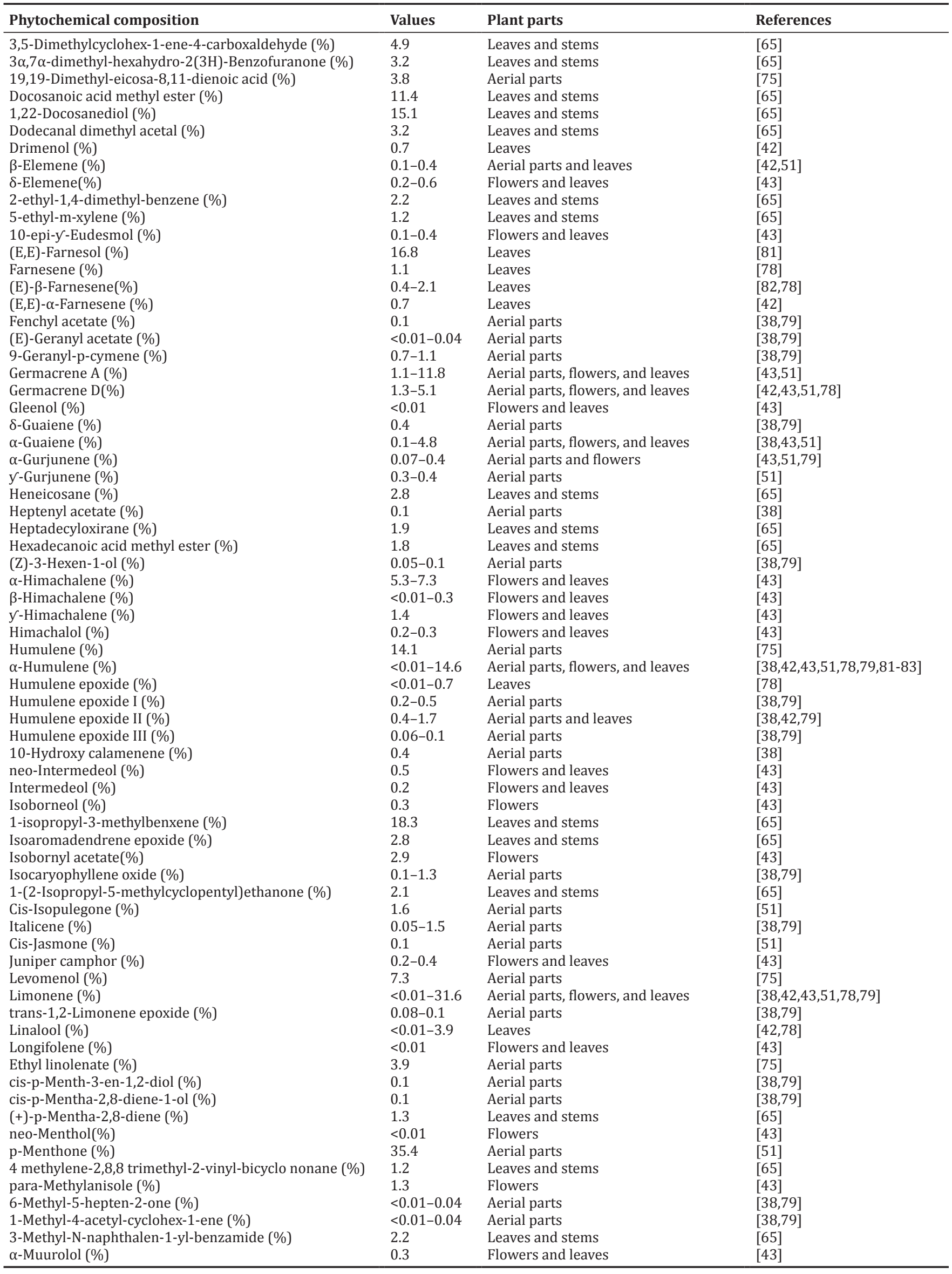


Table 2: (Continued)

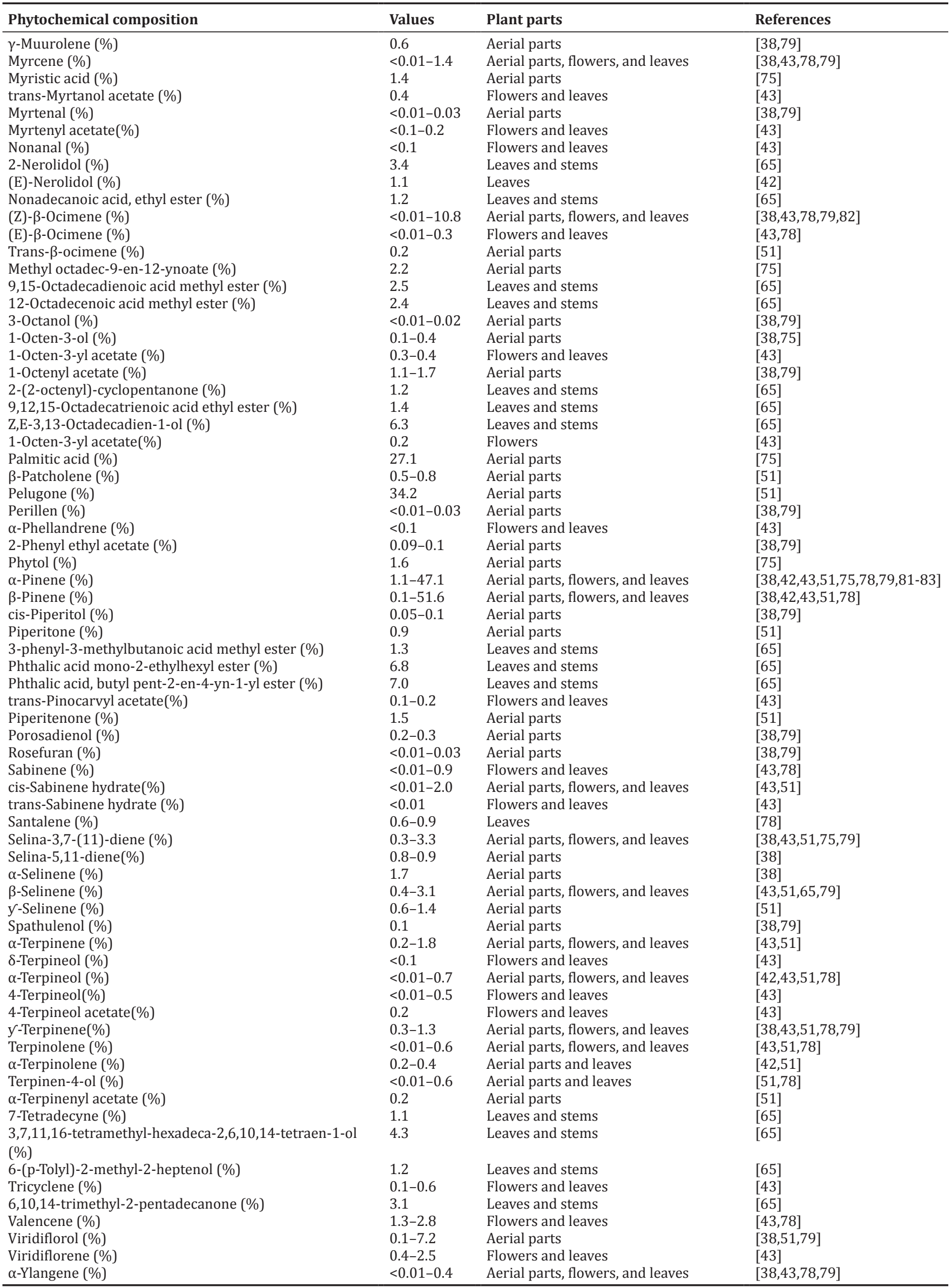


antimycobacterial [61,88], antifungal $[24,38,61,85,86]$, antiinflammatory [89], antioxidant [8,65,88], hepatoprotection [65], hypoglycemic [90], and cytotoxicity and toxicity $[8,42,65,87,90]$.

\section{Antibacterial activities}

Boily and Van Puyvelde [85] evaluated antibacterial activities of methanol flower, leaf, and stem extracts of $H$. odoratissimum against Bacillus subtilis, Mycobacterium smegmatis, Pseudomonas aeruginosa, Salmonella gallinarum, and Staphylococcus aureus using the agar dilution streak method. The flower extract exhibited activities against $B$. subtilis, M. smegmatis, and S. aureus [85]. Van Puyvelde et al. [24] evaluated antibacterial activities of 3,5-dihydroxy-6,7,8-trimethoxy flavone, 3-0-methylquercetin, and helichrysetin against Enterobacter cloaceae, Escherichia coli, Klebsiella pneumoniae, Proteus vulgaris, P. aeruginosa, Pseudomonas solanacearum, Salmonella typhimurium, Serratia marcescens, Shigella dysenteriae, B. subtilis, M. smegmatis, S. aureus, and Streptococcus pyogenes using liquid dilution method with tetracycline hydrochloride as a positive control. The compound 3-0-methylquercetin exhibited activities with minimum inhibitory concentration (MIC) values ranging from $6.3 \mu \mathrm{g} / \mathrm{ml}$ to $100.0 \mu \mathrm{g} / \mathrm{ml}$ which was comparable to MIC values of $0.8 \mu \mathrm{g} / \mathrm{ml}-100.0 \mu \mathrm{g} / \mathrm{ml}$ exhibited by the positive control [24]. Mathekga [86] evaluated the antibacterial activities of acetone extracts of aerial parts of $H$. odoratissimum against Bacillus cereus, Bacillus pumilus, B. subtilis, Micrococcus kristinae, S. aureus, Enterobacter cloacae, E. coli, K. pneumoniae, P. aeruginosa, and S. marcescens using agar dilution method. The extract exhibited activities against $B$. cereus, B. pumilus, B. subtilis, M. kristinae, S. aureus, and E. cloacae with MIC values ranging from $0.01 \mathrm{mg} / \mathrm{ml}$ to $1.0 \mathrm{mg} / \mathrm{ml}$ [86]. Seaman [61] evaluated the antibacterial activities of acetone and methanol leaf extracts of $H$. odoratissimum against $S$. aureus, Enterococcus faecalis, $B$. cereus, P. aeruginosa, K. pneumoniae, Serratia odorifera, and Moraxella catarrhalis using disc diffusion and broth microdilution methods with neomycin and ciprofloxacin as positive controls. The extracts showed activities against $S$. aureus, E. faecalis, and B. cereus with a zone of inhibition ranging from $4.1 \mathrm{~mm}$ to $9.4 \mathrm{~mm}$ and MIC values ranging from $0.5 \mathrm{mg} / \mathrm{ml}$ to $>16.0 \mathrm{mg} / \mathrm{ml}$ [61]. Reddy [38] evaluated antibacterial activities of acetone and methanol extracts of aerial parts of $H$. odoratissimum as well as essential oils isolated from the species against E. coli, Yersinia enterocolitica, Klebsiella pneumoniae, S. aureus, and $B$. cereus using disc diffusion assay with ciprofloxacin $(0.01 \mathrm{mg} / \mathrm{ml})$ as a positive control. The extract exhibited activities against $S$. aureus and B. cereus with MIC values of $<0.25 \mathrm{mg} / \mathrm{ml}$ [38]. Lourens et al. [87] evaluated antibacterial activities of chloroform:methanol (1:1) leaf and stem extracts of $H$. odoratissimum against $S$. aureus, Staphylococcus epidermidis, B. cereus, K. pneumonia, and P. aeruginosa using the 96well microplate method with ciprofloxacin as a positive control. The extracts exhibited activities against $S$. aureus and B. cereus with MIC values ranging of $4.0 \mathrm{mg} / \mathrm{ml}$ and $2.0 \mathrm{mg} / \mathrm{ml}$, respectively [87]. Ocheng et al. [74] evaluated antibacterial activities of hexane and methanol aerial parts extracts of $H$. odoratissimum against bacterial pathogens associated with periodontal diseases and dental caries which included Aggregatibacter actinomycetemcomitans, Porphyromonas gingivalis, Tannerella forsythia, Streptococcus mutans, Streptococcus sobrinus, and Lactobacillus acidophilus using agar well-diffusion and agar-dilution assays with doxycycline $(30 \mu \mathrm{g})$ as a positive control. The extracts were active against all the tested pathogens with the exception of A. actinomycetemcomitans with MIC values ranging from $0.1 \mathrm{mg} / \mathrm{ml}$ to $1.0 \mathrm{mg} / \mathrm{ml}$ [74]. Similarly, Ocheng et al. [75] evaluated the inhibitory effects of the essential oils isolated from the aerial parts of $H$. odoratissimum on P. gingivalis, A. actinomycetemcomitans, S. mutans, Bacillus megaterium, and L. acidophilus using broth dilution methods at concentrations of $1 \%, 0.1 \%$, and $0.01 \%$ with chlorhexidine as the positive control. The most sensitive pathogen was A. actinomycetemcomitans, followed by P. gingivalis, B. megaterium, and S. mutans, with the oil exhibiting limited effects on L. acidophilus [75]. Lawal et al. [42] evaluated antibacterial activities of essential oil isolated from $H$. odoratissimum against B. cereus, B. pumilus, S. aureus, S. aureus, Streptococcus faecalis, E. cloacae, E. coli, K. pneumoniae, P. vulgaris, $P$. vulgaris, $P$. aeruginosa, and Serratia marcescens using the disc diffusion and broth microdilution methods with chloramphenicol $(25 \mu \mathrm{g})$ and tetracycline $(25 \mu \mathrm{g})$ as positive controls. The volatile oil showed potential antibacterial activities against tested microorganisms with mean zones of inhibition and MIC values ranging from $6.7 \mathrm{~mm}$ to $17.0 \mathrm{~mm}$ and $1.3 \mathrm{mg} / \mathrm{mL}$ to $10.0 \mathrm{mg} / \mathrm{mL}$, respectively. These antibacterial activities were comparable to the zone of inhibition of $6.0 \mathrm{~mm}$ to $23.7 \mathrm{~mm}$ and MIC values of $1.3 \mathrm{mg} / \mathrm{mL}$ to $10.0 \mathrm{mg} / \mathrm{mL}$ exhibited by the controls [42].

\section{Antimycobacterial activities}

Lall and Meyer [88] evaluated antimycobacterial activities of acetone and waterleaf extracts of $H$. odoratissimum against the drug-sensitive strain of Mycobacterium tuberculosis using the agar plate method and screened the activities of drug-resistant and drug-sensitive strains of $M$. tuberculosis using rapid radiometric method to confirm the inhibitory activities. The MIC values of acetone extracts against all the strains by both methods were $0.5 \mathrm{mg} / \mathrm{ml}$ [88]. Seaman [61] evaluated the antimycobacterial activities of acetone and waterleaf extracts of $H$. odoratissimum against M. smegmatis and Mycobacterium aurum using broth microdilution technique and M. tuberculosis using BACTEC susceptibility testing with rifampicin and ciprofloxacin as positive controls. The extracts exhibited activities with MIC values ranging from $0.3 \mathrm{mg} / \mathrm{ml}$ to $2.0 \mathrm{mg} / \mathrm{ml}[61]$.

\section{Antifungal activities}

Boily and Van Puyvelde [85] evaluated antifungal activities of methanol flower, leaf, and stem extracts of H. odoratissimum against Candida albicans using the agar dilution streak method. The flower extract exhibited activities against the tested pathogen [85]. Van Puyvelde et al. [24] evaluated antifungal activities of 3,5-dihydroxy-6,7,8trimethoxy flavone, 3-0-methylquercetin and helichrysetin against Aspergillus flavus, C. albicans, Epidermophyton floccosum, Microsporum canis, and Paecilomyces using liquid dilution method with nystatin as a positive control. The compound 3-0-methylquercetin exhibited activities with MIC values ranging from $12.5 \mu \mathrm{g} / \mathrm{ml}$ to $100.0 \mu \mathrm{g} / \mathrm{ml}$ which was comparable to MIC values of $0.8 \mu \mathrm{g} / \mathrm{ml}-100.0 \mu \mathrm{g} / \mathrm{ml}$ exhibited by the positive control [24]. Mathekga [86] evaluated the antifungal activities of acetone extracts of aerial parts of $H$. odoratissimum against A. flavus, Aspergillus niger, Cladosporium cladosporioides, Cladosporium cucumerinum, Cladosporium sphaerospermum, and Phytophthora capsici using agar dilution method. The extract exhibited activities against all tested pathogens with MIC values ranging from $0.01 \mathrm{mg} / \mathrm{ml}$ to $0.1 \mathrm{mg} / \mathrm{ml}$ [86]. Seaman [61] evaluated the antibacterial activities of acetone and methanol leaf extracts of $H$. odoratissimum against C. albicans using disc diffusion and broth microdilution methods with neomycin and ciprofloxacin as positive controls. The extract showed activities with MIC values ranging from $2.0 \mathrm{mg} / \mathrm{ml}$ to $8.0 \mathrm{mg} / \mathrm{ml}$ [61]. Reddy [38] evaluated antifungal activities of acetone and methanol extracts of aerial parts of $H$. odoratissimum as well as essential oils isolated from the species against Cryptococcus neoformans, C. albicans, and Alternaria alternata using disc diffusion assay with nystatin (30 $\mu \mathrm{g}$ ) as a positive control. The acetone extract exhibited activities with a zone of inhibition of $2 \mathrm{~mm}$ and $3 \mathrm{~mm}$ against Cryptococcus neoformans and C. albicans, respectively [38].

\section{Anti-inflammatory activities}

Frum and Viljoen [89] evaluated anti-inflammatory activities of aqueous and methanol leaf extracts of H. odoratissimum as well as essential oils isolated from the species through the assessment of the 5 -lipoxygenase inhibitory activities using a three-fold stepwise dilution method with dimethyl sulfoxide and Tween ${ }^{\circledR} 20$ as negative controls and nordihydroguaiaretic acid as a positive control. The essential oils displayed 5-lipoxygenase inhibitory activities with half maximal inhibitory concentration $\left(\mathrm{IC}_{50}\right.$ ) values of $22.5 \mathrm{ppm}-35.9 \mathrm{ppm}$ [89].

\section{Antioxidant activities}

Legoale et al. [80] evaluated the antioxidant activities of the flavonoid 3, 4',3,5-tetrahydroxy-7-methoxyflavone isolated from $H$. odoratissimum using the 2,2-diphenyl-1-picrylhydrazyl (DPPH) radical scavenging 
assay. The flavonoid exhibited antioxidant activities of 32.3\% [80]. Frum and Viljoen [89] evaluated the antioxidant activities of aqueous and methanol leaf extracts of $H$. odoratissimum as well as essential oils isolated from the species using the DPPH radical scavenging assay. The essential oils displayed weak DPPH antioxidant activities with an $\mathrm{IC}_{50}$ value of $>100 \mathrm{ppm}$ [89]. Twilley and Lall [8] evaluated the antioxidant activities of the ethanol leaf extracts of $H$. odoratissimum using the DPPH free radical scavenging assay. The extract showed good DPPH activities with an $\mathrm{IC}_{50}$ value of $5.1 \mu \mathrm{g} / \mathrm{ml}$ [8]. Twilley et al. [65] evaluated the antioxidant activities of ethanol leaf and stem extracts of $H$. odoratissimum using the DPPH free-radical scavenging, nitric oxide inhibition (NO), hydrophilic oxygen radical absorbance capacity (H-ORAC), and lipophilic oxygen radical absorbance capacity (L-ORAC) assays. The extracts showed good DPPH activities with $\mathrm{IC}_{50}$ values of $5.1 \mu \mathrm{g} / \mathrm{ml}$; however, the extract showed low NO scavenging activity with $\mathrm{IC}_{50}$ values of $>100.0 \mu \mathrm{g} / \mathrm{ml}$. The H-ORAC and L-ORAC values of the extracts were found to be $2542 \mu$ moles and $3648 \mu$ moles of Trolox equivalents per gram of extract, respectively [65].

\section{Hepatoprotection activities}

Twilley et al. [65] evaluated the in vitro hepatoprotection activities of the ethanol leaf and stem extracts of $H$. odoratissimum on the liver hepatocellular carcinoma (HepG2) cells before the hepatoprotective assay to determine the appropriate doses to be tested in the assay. The extract showed significant hepatoprotection at $25 \mu \mathrm{g} / \mathrm{ml}$ on HepG2 cells exposed to D-galactosamine [65]

\section{Hypoglycemic activities}

Njagi et al. [90] evaluated hypoglycemic activities of aqueous leaf extracts of $H$. odoratissimum by administering $50 \mathrm{mg} / \mathrm{kg}$ body weight, $100 \mathrm{mg} / \mathrm{kg}$ body weight, and $150 \mathrm{mg} / \mathrm{kg}$ body weight in alloxan-induced diabetic Swiss albino mice. The extract exhibited a non-dose dependent response by lowering blood glucose levels in diabetic mice [90].

\section{Cytotoxicity and toxicity activities}

Lourens et al. [87] evaluated in vitro cytotoxicity activities of chloroform:methanol (1:1) leaf and stem extracts of $H$. odoratissimum against transformed human kidney epithelial (Graham) cells, MCF-7 breast adenocarcinoma, and SF-268 glioblastoma cells at a concentration of $0.1 \mathrm{mg} / \mathrm{ml}$ using the sulforhodamine B assay. The extract exhibited Graham cell growth ranging from $7.4 \%$ to $48.2 \%$ at the tested concentration [87], implying that the species may be toxic againstGraham cells. Lawal et al. [42] evaluated the cytotoxicity of essential oils isolated from $H$. odoratissimum using the brine shrimp assay. The essential oil of $H$. odoratissimum showed significant cytotoxicity against the brine shrimp with median lethal concentration value of $31.62 \mu \mathrm{g} / \mathrm{mL}$ [42]. Twilley and Lall [8] evaluated the cytotoxicity activities of ethanol leaf extracts of $H$. odoratissimum against human epidermoid carcinoma (A431) and non-cancerous cell lines such as Chang liver cells, human embryonic kidney cells (Hek293), and mouse melanocyte cells (B16F10) using the 2,3-Bis-(2-methoxy-4-nitro-5-sulfophenyl]-2H-tetrazolium-5carboxyanilide salt (XTT) method. The extracts exhibited activities with $\mathrm{IC}_{50}$ values ranging from $15.5 \mu \mathrm{g} / \mathrm{ml}$ to $57.4 \mu \mathrm{g} / \mathrm{ml}$ against the tested line cell [8]. Twilley et al. [65] evaluated the cytotoxicity activities of the ethanol leaf and stem extracts of H. odoratissimum against human epidermoid carcinoma (A431), malignant melanoma (A375), cervical epithelial carcinoma (HeLa), and human embryonic kidney (HEK-293) cells using the XTT method. The extracts showed inhibitory activities with $\mathrm{IC}_{50}$ values ranging from $15.5 \mu \mathrm{g} / \mathrm{ml}$ to $55.5 \mu \mathrm{g} / \mathrm{ml}$ with a selectivity index value of 2.4 [65]. Njagi et al. [90] evaluated acute toxicity of the leaf aqueous extract of $H$. odoratissimum using Swiss albino mice by administering orally to mice a dose of $450 \mathrm{mg} / \mathrm{kg}$ body weight of the extract for 30 days. The animals were observed for any signs of acute toxicity such as hypoactivity, piloerection, and salivation. The animals showed mild perihepatitis and perivascular inflammation in the kidneys, while the renal cells, hepatocytes, and spleen tissue cells were intact, and the liver and heart muscle had no signs of pathology [90]. Therefore, the species showed no discernible toxicity on the major organs of the studied animals.

\section{CONCLUSION}

In this review, the medicinal uses, phytochemistry, biological activities, and toxicity of different extracts and compounds of $H$. odoratissimum have been summarized. The diverse medicinal uses of $H$. odoratissimum and the preliminary phytochemical and ethnopharmacological studies carried so far indicates that the species has potential as herbal medicine. Therefore, there is a need to validate the documented ethnomedicinal uses of $H$. odoratissimum through phytochemical and pharmacological studies. Although contemporary ethnopharmacological research involving $H$. odoratissimum is promising, it is too preliminary and sometimes too general to be used to explain and support some of the medicinal uses of the species. Therefore, future studies should address these knowledge gaps through experimental animal studies, randomized clinical trials, and target-organ toxicity studies involving $H$. odoratissimum crude extracts and compounds isolated from the species.

\section{ACKNOWLEDGMENTS}

I would like to express my gratitude to the National Research Foundation, South Africa and Govan Mbeki Research and Development Centre, University of Fort Hare for financial support to conduct this study.

\section{AUTHOR'S CONTRIBUTIONS}

The author declares that this work was done by the author named in this article.

\section{CONFLICTS OF INTEREST}

The author declares that they have no conflicts of interest.

\section{REFERENCES}

1. Hutchinson J, Dalziel JM. Flora of West Tropical Africa. London: Crown Agents for Overseas Governments and Administration; 1963.

2. Hilliard OM. Gnaphaliinae. In: Leistner OA, editor. Flora of Southern Africa: Asteraceae. Pretoria: National Botanical Institute; 1983. p. 1-325.

3. Goldblatt P, Manning JC. Cape Plants: A Conspectus of the Cape Flora of South Africa. Strelitzia Cape Town. Vol. 9. South Africa: National Botanical Institute; 2000

4. Beentje HJ. Compositae, part 2. In: Beentje HJ, Smith SA, editors. Flora of Tropical East Africa. London: Crown Agents for Overseas Governments and Administration; 2002. p. 1-315.

5. Germishuizen G, Meyer NL. Plants of Southern Africa: An Annotated Checklist. Strelitzia, Vol. 14. Pretoria: National Botanical Institute; 2003.

6. Figueiredo E, Smith GF. Plants of Angola. Strelitzia, Vol. 22. Pretoria: South African National Biodiversity Institute; 2008

7. Swelankomo N. Helichrysum odoratissimum (L.) Sweet; 2004. Available from: http://www.pza.sanbi.org/helichrysum-odoratissimum. [Last accessed on $2019 \mathrm{Feb} 20]$.

8. Twilley D, Lall N. Extracts and Compositions of Helichrysum odoratissimum for Preventing and Treating Skin Cancers. United States Patent No. US2016/0235797 A1; 2016. Available from: https://www. patentimages.storage.googleapis.com/51/39/56/c739d2695f065d/ WO2015049666A1.pdf. [Last accessed on 2016 Mar 20].

9. Williams VL, Balkwill K, Witkowski ET. A lexicon of plants traded in the Witwatersrand umuthi shops. Bothalia 2001;31:71-98.

10. Dold AP, Cocks ML. The trade in medicinal plants in the Eastern Cape province, South Africa. S Afr J Sci 2002;98:589-97.

11. Van Wyk BE, Oudtshoorn BV, Gericke N. Medicinal Plants of South Africa. Pretoria: Briza Publications; 2013.

12. Petersen LM, Charman AJ, Moll EJ, Collins RJ, Hockings MT. Bush doctors and wild medicine: The scale of trade in Cape Town's informal economy of wild-harvested medicine and traditional healing. Soc Nat Res 2014;27:315-36.

13. Philander LE, Makunga NP, Esler KJ. The informal trade of medicinal plants by Rastafari bush doctors in the Western Cape of South Africa. Econ Bot 2014;68:303-15

14. Van Wyk BE. The potential of South African plants in the development of new medicinal products. S Afr J Bot 2011;77:812-29.

15. Van Wyk BE. A review of commercially important African medicinal 
plants. J Ethnopharmacol 2015;176:118-34

16. Van Wyk BE. A review of African medicinal and aromatic plants. In: Nefati M, Najjaa H, Máthé A, editors. Medicinal and Aromatic Plants of the World: Africa. Dordrecht: Springer; 2017. p. 19-60.

17. Maroyi A. Helichrysum petiolare Hilliard and B.L. Burtt: Review of its medicinal uses, phytochemistry and biological activities. Asian J Pharm Clin Res 2019;12:32-7.

18. Maroyi A. Dicoma anomala Sond: A review of its botany, ethnomedicine, phytochemistry and pharmacology. Asian J Pharm Clin Res 2018;11:70-7.

19. Cook FE. Economic Botany Data Collection Standard. Prepared for the International Working Group on Taxonomic Databases for Plant Sciences (TDWG). London, Kew: Kew Royal Botanic Gardens; 1995.

20. Macía MJ, Armesilla PJ, Cámara-Leret R, Paniagua-Zambrana N, Villalba S, Balslev H, et al. Palm uses in North Western South America: A quantitative review. Bot Rev 2011;77:462-570.

21. Gruca M, Cámara-Leret R, Macía MJ, Balslev H. New categories for traditional medicine in the economic botany data collection standard. J Ethnopharmacol 2014;155:1388-92.

22. Staub PO, Geck MS, Weckerle CS, Casu L, Leonti M. Classifying diseases and remedies in ethnomedicine and ethnopharmacology. J Ethnopharmacol 2015;174:514-9.

23. Maliehe EB. Medicinal Plants and Herbs of Lesotho. Maseru: Mafeteng Development Project; 1997.

24. Van Puyvelde L, De Kimpe N, Costa J, Munyjabo V, Nyirankuliza S, Hakizamungu E, et al. Isolation of flavonoids and a chalcone from Helichrysum odoratissimum and synthesis of helichrysetin. J Nat Prod 1989;52:629-33.

25. Heyman H. Identification of anti-HIV Compounds in Helichrysum Species (Asteraceae) by Means of NMR-based Metabolomics Guided Fractionation. Ph D Thesis. Pretoria: University of Pretoria; 2013.

26. Kose LS, Moteetee A, Van Vuuren S. Ethnobotanical survey of medicinal plants used in the Maseru district of Lesotho. J Ethnopharmacol 2015; $170: 184-200$

27. Hulley IM, Van Wyk BE. Quantitative medicinal ethnobotany of Kannaland (Western Little Karoo, South Africa): Non-homogeneity amongst villages. S Afr J Bot 2019;122:225-65.

28. Philander LA. An ethnobotany of Western Cape Rasta bush medicine. J Ethnopharmacol 2011;138:578-94.

29. Erasto P, Adebola P, Grierson D, Afolayan AJ. An ethnobotanical study of plants used for the treatment of diabetes in the Eastern Cape Province, South Africa. Afr J Biotechnol 2005;4:1458-60.

30. Mahop MT, Mayet M. En route to biopiracy? Ethnobotanical research on anti-diabetic medicinal plants in the Eastern Cape Province, South Africa. Afr J Biotechnol 2007;6:2945-52.

31. Maroyi A. Diversity of use and local knowledge of wild and cultivated plants in the Eastern Cape province, South Africa. J Ethnobiol Ethnomed 2017;13:43.

32. Sabiu S, Madende M, Ajao AA, Ogundeji OA, Lekena N, Alayande KA. The scope of phytotherapy in Southern African antidiabetic healthcare. Trans R Soc S Afr 2019;74:1-18.

33. Sewani-Rusike CR, Mammen M. Medicinal plants used as home remedies: A family survey by first year medical students. Afr J Tradit Complement Altern Med 2014;11:67-72.

34. Guillarmod AJ. Flora of Lesotho (Basutoland). Lehre: Cramer; 1971.

35. Schmitz MO. Wild Flowers of Lesotho. Roma: ESSA; 1982.

36. Hutchings A, Scott AH, Lewis G, Cunningham AB. Zulu Medicinal Plants: An Inventory. Pietermaritzburg: University of Natal Press; 1996.

37. Long C. Swaziland's Flora: SiSwati Names and Uses. Swaziland National Trust Commission, Mbambane; 2005. Available from: http:// www.sntc.org.sz/index.asp. [Last accessed on 2019 Feb 04]

38. Reddy D. The phytochemistry and Antimicrobial Activity of Selected Indigenous Helichrysum species. MSc Dissertation. Johannesburg: University of the Witwatersrand; 2007.

39. Van Wyk BE, Gericke N. Peoples Plants: A Guide to Useful Plants of Southern Africa. Pretoria: Briza Publications; 2007.

40. Odeyemi OO, Masika P, Afolayan AJ, Evaluation of the activities of five essential oils against the stored maize weevil. Nat Prod Commun 2008;3:1097-102.

41. Moteetee A, Van Wyk BE. The medical ethnobotany of Lesotho: A review. Bothalia 2011;41:209-28

42. Lawal OA, Ogunwande IA, Kasali AA, Opoku AR, Oyedeji AO. Chemical composition, antibacterial and cytotoxic activities of essential oil from the leaves of Helichrysum odoratissimum grown in South Africa. J Essent Oil Bearing Plants 2015;18:236-41

43. Giovanelli S, De Leo M, Cervelli C, Ruffoni B, Ciccarelli D, Pistelli L, et al. Essential oil composition and volatile profile of seven Helichrysum species grown in Italy. Chem Biodivers 2018;15:e1700545.

44. Moteetee A, Moffett RO, Seleteng-Kose L. A review of the ethnobotany of the Basotho of Lesotho and the Free State province of South Africa (South Sotho). S Afr J Bot 2019;122:21-56

45. Hutchings A, van Staden J. Plants used for stress-related ailments in traditional Zulu, Xhosa and Sotho medicine. Part 1: Plants used for headaches. J Ethnopharmacol 1994;43:89-124.

46. van Wyk BE. A review of Khoi-san and cape Dutch medical ethnobotany. J Ethnopharmacol 2008;119:331-41.

47. Olorunnisola OS, Bradley G, Afolayan AJ. Ethnobotanical information on plants used for the management of cardiovascular diseases in Nkonkobe Municipality, South Africa. J Med Plants Res 2011;5:4256-60.

48. Van Wyk BE, Gorelik B. The history and ethnobotany of Cape herbal teas. S Afr J Bot 2017;110:18-38

49. Albayrak S, Sagdic O, Aksoy A, Hamzaoglu E. Antimicrobial and antioxidant activities of Helichrysum species from the Mediterranean region of Turkey. Asian J Chem 2008;20:3143-52

50. Hutchings A. Zulu Medicinal Plants. Pietermaritzburg: University of Natal Press; 1996.

51. Asekun OT, Grierson DS, Afolayan AJ. Characterization of essential oils from Helichrysum odoratissimum using different drying methods. J Appl Sci 2007;7:1005-8.

52. Lall N, Kishore N. Are plants used for skin care in South Africa fully explored? J Ethnopharmacol 2014;153:61-84

53. Mugomeri E, Chatanga P, Raditladi T, Makara M, Tarirai C. Ethnobotanical study and conservation status of local medicinal plants: Towards a repository and monograph of herbal medicines in Lesotho. Afr J Tradit Complement Altern Med 2016;13:143-56.

54. Njoroge NG, Bussmann WR, Gemmill B, Newton LE, Ngumi VW. Utilisation of weed species as sources of traditional medicines in central Kenya. Lyonia 2004;7:272-87.

55. Wintola OA, Afolayan AJ. An inventory of indigenous plants used as anthelmintics in Amathole district municipality of the Eastern Cape province, South Africa. Afr J Tradit Complement Altern Med 2014; $12: 112-21$

56. Ramathal DC, Ngassapa OD. Medicinal plants used by Rwandese traditional healers in refugee camps in Tanzania. Pharm Biol 2001;39:132-7.

57. Watt JM, Breyer-Brandwijk MG. The Medicinal and Poisonous Plants of Southern and Eastern Africa. Edinburgh: E and S Livingstone; 1962.

58. Hutchings A, Johnson CT. Glimpses of a Xhosa herbal. Veld Flora 1986;72:59-62.

59. Kokwaro J. Medicinal Plants of East Africa. Nairobi: Kenya Literature Bureau; 1993

60. Braithwaite MC. A Laboratory Model for Studying Inhalation Therapy in Traditional Healing Rites. MSc Dissertation. Johannesburg: University of the Witwatersrand; 2007

61. Seaman T. The Antimicrobial and Antimycobacterial Activity of Plants Used for the Treatment of Respiratory Ailments in Southern Africa and the Isolation of Anacardic acid from Ozoroa paniculosa. MSc Dissertation. Johannesburg: University of the Witwatersrand; 2005.

62. Tabuti JR, Kukunda CB, Waako PJ. Medicinal plants used by traditional medicine practitioners in the treatment of tuberculosis and related ailments in Uganda. J Ethnopharmacol 2010;127:130-6.

63. Chinsembu KC. Tuberculosis and nature's pharmacy of putative antituberculosis agents. Acta Trop 2016;153:46-56.

64. Madisha JK. Antimycobacterial Activities of Selected Plants Used in the Management of Tuberculosis in Sekhukhune (Limpopo province), South Africa. MSc Dissertation. Bloemfontein: University of the Free State; 2017

65. Twilley D, Kishore N, Meyer D, Moodley I, Kumar V, Lall N. The effect of Helichrysum odoratissimum (L.) Sweet on cancer cell proliferation and cytokine production. Int J Pharmacogn Phytochem Res 2017;9:621-31.

66. Semenya SS, Maroyi A. Data on medicinal plants used to treat respiratory infections and related symptoms in South Africa. Data Brief 2018;21:419-23.

67. Cocks M, Dold AP. Cultural significance of biodiversity: The role of medicinal plants in urban African cultural practices in the Eastern Cape, South Africa. J Ethnobiol 2006;26:60-81.

68. Moteetee A. A review of plants used for magic by Basotho people in comparison with other cultural groups in southern Africa. Indian $\mathrm{J}$ Tradit Knowl 2017;16:229-34.

69. Lourens AC, Reddy D, Başer KH, Viljoen AM, Van Vuuren SF. In vitro biological activity and essential oil composition of four indigenous 
South African Helichrysum species. J Ethnopharmacol 2004;95:253-8.

70. Mabona U. Antimicrobial Activity of Southern African Medicinal Plants with Dermatological Relevance. MSc Dissertation. Johannesburg: University of the Witwatersrand; 2013.

71. Mabona U, Van Vuuren SF. Southern African medicinal plants used to treat skin diseases. S Afr J Bot 2013;87:175-93.

72. Afolayan AJ, Grierson DS, Mbeng WO. Ethnobotanical survey of medicinal plants used in the management of skin disorders among the Xhosa communities of the Amathole district, Eastern Cape, South Africa. J Ethnopharmacol 2014;153:220-32.

73. Mubiru NK, Kakooko AB, Alia AM, Mutyasba JB, Apio SK, Amai CA, et al. Ethnomedicine in Uganda. Kampala: National Chemotherapeutic Research Laboratory, Ministry of Health; 1995.

74. Ocheng F, Bwanga F, Joloba M, Borg-Karlson AK, Gustafsson A, Obua C. Anti-bacterial activities of extracts from Ugandan medicinal plants used for oral care. J Ethnopharmacol 2014;155:852-85.

75. Ocheng F, Bwanga F, Joloba M, Softrata A, Azeem M, Pütsep K, et al. Essential oils from Ugandan aromatic medicinal plants: Chemical composition and growth inhibitory effects on oral pathogen. Evid Based Complement Altern Med 2015;2015:230832.

76. Ocheng F. Ugandan Medicinal Plants Used Traditonally for Oral Care: Investigation of Extracts for Anti-bacterial, Cytotoxic and Antiinflammatory Effects. Ph D Thesis. Stockholm: Karolinska Institutet; 2015 .

77. Biholong M. Contribution à L'étude de la Flore du Cameroun: Les Astéracées. Thèse de Doctorat. Brussels: D’Université de Bordeaux III; 1986.

78. Kuiate JR, Zollo PH, Nguefa EH, Bessière JM, Lamaty G, Menut C. Composition of the essential oils from the leaves of Microglossa pyrifolia (Lam.) O. Kuntze and Helichrysum odoratissimum (L.) Less. growing in Cameroon. Flavour Fragr J 1999;14:82-4.

79. Frum Y, Viljoen AM. In vitro 5-lipoxygenase and anti-oxidant activities of South African medicinal plants commonly used topically for skin diseases. Skin Pharmacol Physiol 2006;19:329-35.
80. Legoalea PB, Mashimbyeb MJ, van Rec T. Antiinflammatory and antioxidant flavonoids from Helichrysum kraussii and H. odoratissimum flowers. Nat Prod Commun 2013;8:1403-4

81. Gundidza MG, Zwaving JH. The chemical composition of the leaf essential oil of Helichrysum odoratissimum Sweet from Zimbabwe. J Essent Oil Res 1993;5:341-3.

82. Lwande W, Hassanali A, Wanyama OB, Ngola S, Mwangi JW. Constituents of the essential oil of Helichrysum odoratissimum (L.) Less. J Essent Oil Res 1993;5:93-5.

83. Kajangwe V, Tomani JC, Mukazayire MJ, Chalchat JC, Duez P. Chemical composition and antibacterial activity of essential oils of 3 Helichrysum species. Planta Med 2008;74:117.

84. Ras AM. Essential oil yield and composition of three Helichrysum species occurring in the Eastern Cape province of South Africa. S Afr J Bot 2013;86:181.

85. Boily Y, Van Puyvelde L. Screening of medicinal plants of Rwanda (Central Africa) for antimicrobial activity. J Ethnopharmacol 1986;16:1-3.

86. Mathekga AD. Antimicrobial Activity of Helichrysum Species and the Isolation of a New Phloroglucinol from Helichrysum caespititium. $\mathrm{Ph}$ D Dissertation. Pretoria: University of Pretoria; 2001.

87. Lourens AC, Van Vuuren SF, Viljoen AM, Davids H, Van Heerden FR. Antimicrobial activity and in vitro cytotoxicity of selected South African Helichrysum species. S Afr J Bot 2011;77:229-35.

88. Lall N, Meyer JJ. In vitro inhibition of drug-resistant and drug-sensitive strains of Mycobacterium tuberculosis by ethnobotanically selected South African plants. J Ethnopharmacol 1999;66:347-54.

89. Frum Y, Viljoen AM. In vitro 5-lipoxygenase activity of three indigenous South African aromatic plants used in traditional healing and the stereospecific activity of limonene in the 5-lipoxygenase assay. J Essent Oil Res 2006;18:85-8.

90. Njagi JM, Ngugi MP, Kibiti CM, Ngeranwa J, Njue W, Gathumbi P, et al. Hypoglycemic effect of Helichrysum odoratissimum in alloxan induced diabetic mice. J Phytopharmacol 2015;4:30-3. 